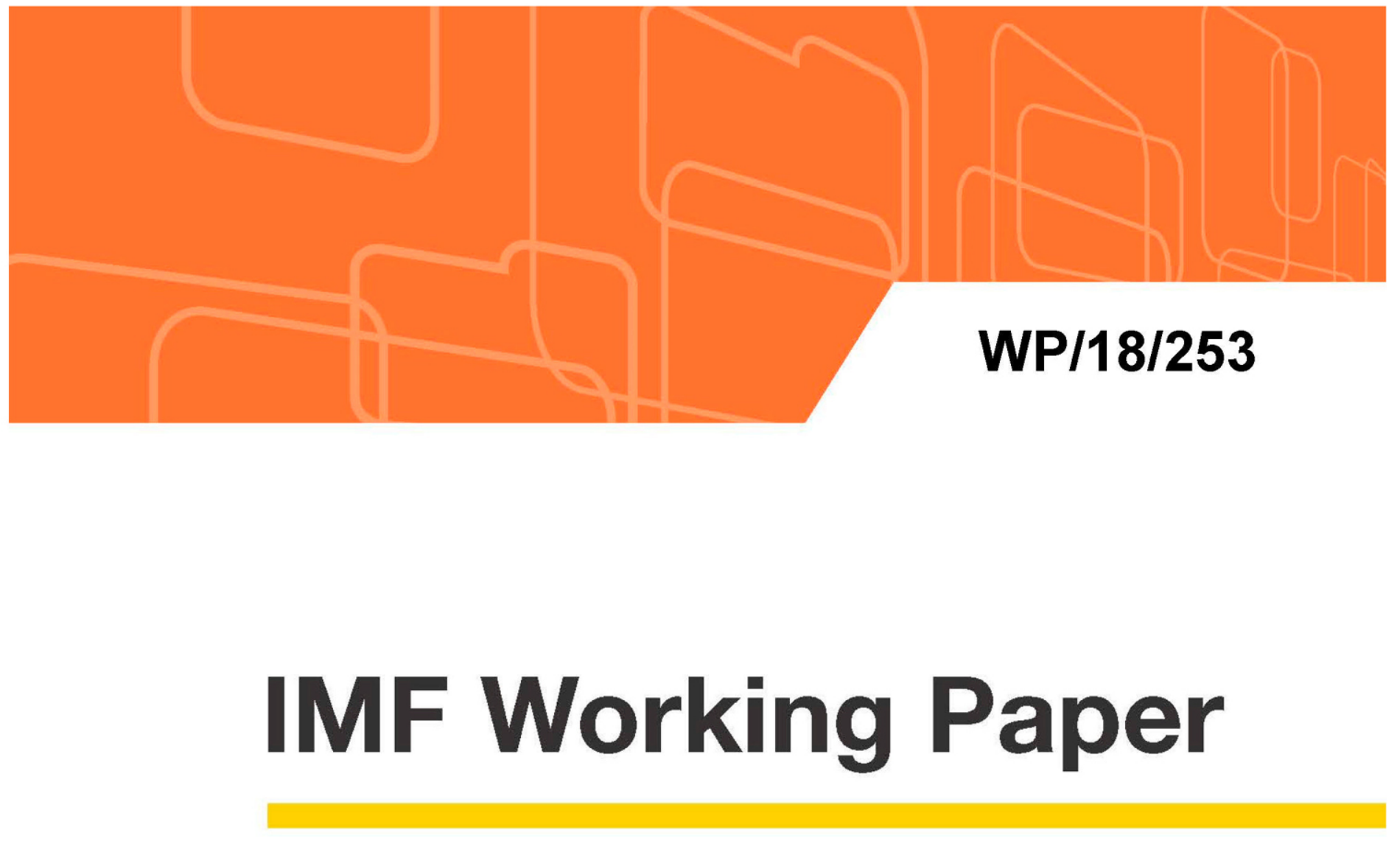

\title{
China's Bond Market and Global Financial Markets
}

by Eugenio Cerutti and Maurice Obstfeld

IMF Working Papers describe research in progress by the authors and are published to elicit comments and to encourage debate. The views expressed in IMF Working Papers are those of the authors and do not necessarily represent the views of the IMF, its Executive Board, or IMF management. 


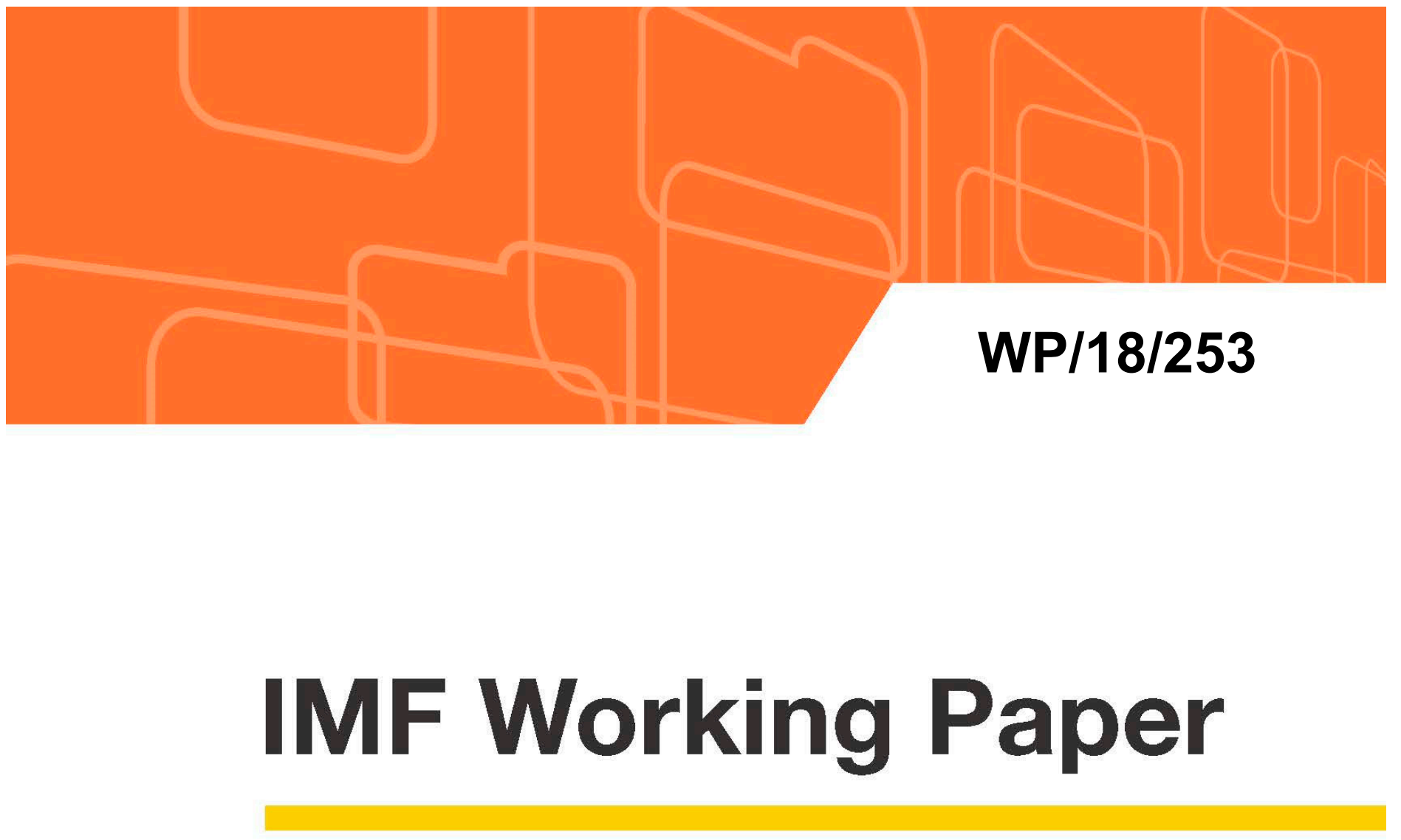

\section{China's Bond Market and Global Financial Markets}

by Eugenio Cerutti and Maurice Obstfeld

IMF Working Papers describe research in progress by the authors and are published to elicit comments and to encourage debate. The views expressed in IMF Working Papers are those of the authors and do not necessarily represent the views of the IMF, its Executive Board, or IMF management.

I N T E R N A T I O N A L M O N E T A R Y F U N D 


\title{
IMF Working Paper
}

Research Department

\section{China's Bond Market and Global Financial Markets \\ Prepared by Eugenio Cerutti and Maurice Obstfeld*}

Authorized for distribution by Maurice Obstfeld

October 2018

\begin{abstract}
IMF Working Papers describe research in progress by the author(s) and are published to elicit comments and to encourage debate. The views expressed in IMF Working Papers are those of the author(s) and do not necessarily represent the views of the IMF, its Executive Board, or IMF management.
\end{abstract}

\begin{abstract}
A cross-country comparative analysis shows that there is substantial room for further integration of China into global financial markets, especially in the case of the international bond market. A further successful liberalization of the Chinese bond market would encompass not only loosening bond market regulations, but also further developing of other markets, notably the foreign exchange market. Even though the increased integration of China into international capital markets would increase its exposure to the global financial cycle, the costs in terms of monetary autonomy would not be large given China's size and especially under a well-articulated macroeconomic framework.
\end{abstract}

JEL Classification: F36, F44, G15

Keywords: China, Bond Market, Market Integration, Globalization

Authors’ E-Mail Addresses: ecerutti@imf.org, mobstfeld@imf.org

\footnotetext{
*Cerutti and Obstfeld are both at the Research Department of the International Monetary Fund (IMF). This paper is a chapter of the forthcoming book "China's Bond Market Taken Off: Characteristics, Prospects, and Reform," edited by Alfred Schipke, Markus Rodlauer, and Zhang Longmei. We are grateful to Qianying Chen, Sally Chen, Sophia Chen, Ziya Gorpe, Henry Hoyle, Deniz Igan, Sole Martinez Peria, Hui Miao, Lev Ratnovski, Alfred Schipke, Yu Shi, Jochen Schmittmann for comments, and to Haonan Zhou for superb help with the data and figures. Emails: ecerutti@imf.org, mobstfeld@imf.org. The opinions expressed herein are solely the responsibility of the authors and should not be interpreted as reflecting those of the IMF, its Executive Board, or IMF management.
} 
Contents

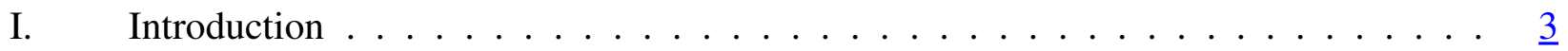

II. China's Financial Markets in the Global Context . . . . . . . . . . . . . . . . $\underline{3}$

III. Further Liberalization of China's Bond Market . . . . . . . . . . . . . . . . . . $\underline{6}$

IV. Market Opening and Increasing External Influences . . . . . . . . . . . $\underline{9}$

V. Sensitivity of Capital Inflows to the Global Financial Cycle . . . . . . . . . . . 12

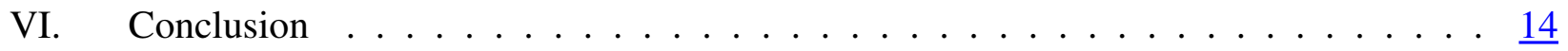

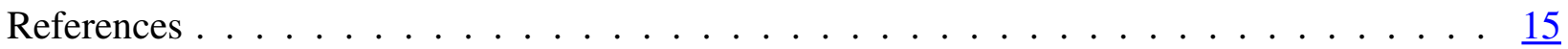

Figures

Figure 1: China's bond and stock market capitalization and bank assets . . . . . . . . 4 Figure 2: $\quad$ Foreign participation in China's stock and bond markets (assets held by overseas entities as \% of market size $\ldots \ldots \ldots \ldots \ldots$

Figure 3: $\quad$ Foreign participation in China's stock and bond markets . . . . . . . $\underline{5}$

Figure 4: International Investment Position . . . . . . . . . . . . .

Figure 5: Total value of bond outstanding, end 2017 (USD trillions) . . . . . . . . $\underline{7}$

Figure 6: $\quad$ Breakdown of foreign holdings by type of bonds, 2016 (percent of total) . . . . $\underline{7}$

Figure 7: Yield curve of government bonds (percent) . . . . . . . . . $\underline{8}$

Figure 8: $\quad$ FX-hedged and unhedged yield differentials . . . . . . . . . . . . . . $\underline{9}$

Figure 9: Gross capital inflow (percent of GDP) . . . . . . . . . . . . 10

Figure 10: Fed's balance sheet and capital portfolio flows to emerging markets . . . . . 11

Figure 11: Analyzing the evolution of the US dollar . . . . . . . . . . . . . 12

Figure 12: Sensitivity to EM common factors by type of capital flow (percent of total variance accounted by the common global factor) . . . . . . . . . . . . . 13

Figure 13: Exposure to global investors and sensitivity to the Global Financial Crisis . . . 14 


\section{INTRODUCTION}

Sustainably integrating China into the global economy is a key part of recent world history and will continue to lead global economic developments. Trade and production integration naturally came first as market-based reforms began more than four decades ago, but integration into global financial markets is now becoming a central issue. Smooth integration will ensure world resources are channeled to their most productive uses globally and that global risks are efficiently shared across countries and sectors-both China and its trade partners stand to benefit.

This paper offers a preliminary assessment of the potential for China's further integration into global financial markets - especially, into the international bond market - and highlights the possible challenges of further financial integration.

The paper uses a two-step approach. The first half benchmarks the increasingly central role of China in global financial markets by analyzing their evolution and comparing them to key international markets, such as the United States, euro area, Japan, and regional peers like India and Korea. It then analyzes foreign participation in Chinese bonds as well as bond yield differentials (such as differences between foreign-exchange-hedged and unhedged yields). The results make clear that further successful liberalization of the Chinese bond market would encompass not only the bond market itself, but also further development of other markets, notably the foreign exchange market.

The second half focuses on the potential challenges of further international integration of the Chinese bond market. The ongoing normalization of U.S. monetary policy, for example, could pose risks for many emerging economies, including China. The paper therefore explores the sensitivity of China's capital inflows to the global financial cycle and evaluates how this could increase as integration proceeds. It concludes that room is ample for further integration, especially in the bond market, but this process cannot occur in isolation given the broader economic integration necessary for sustainable efficiency and stability.

\section{China's Financial Markets in the Global Context}

As noted, China is becoming increasingly important in global financial markets, reflecting the growth of its financial markets relative to the size of the real domestic economy (Figure 1, panel 1) and the fast-growing real economy itself, with its rising ratio to world GDP. The figure's right panel shows that Chinese bond market capitalization stood at about 1 percent of global GDP at the start of the 2000s, but had reached 9 percent by the end of 2017.

Rising stock market capitalization is a bit smaller but still striking, reaching about 10 percent in 2017, from about 2 percent of global GDP in 2002. Much more impressive-but also pointing to potential financial stability challenges - the assets of the Chinese banking system skyrocketed from 1 percent of global GDP in 2002 to about 40 percent in 2017.

At the same time, foreign participation in China's stock and bond markets has risen, although it 
Figure 1: China's bond and stock market capitalization and bank assets

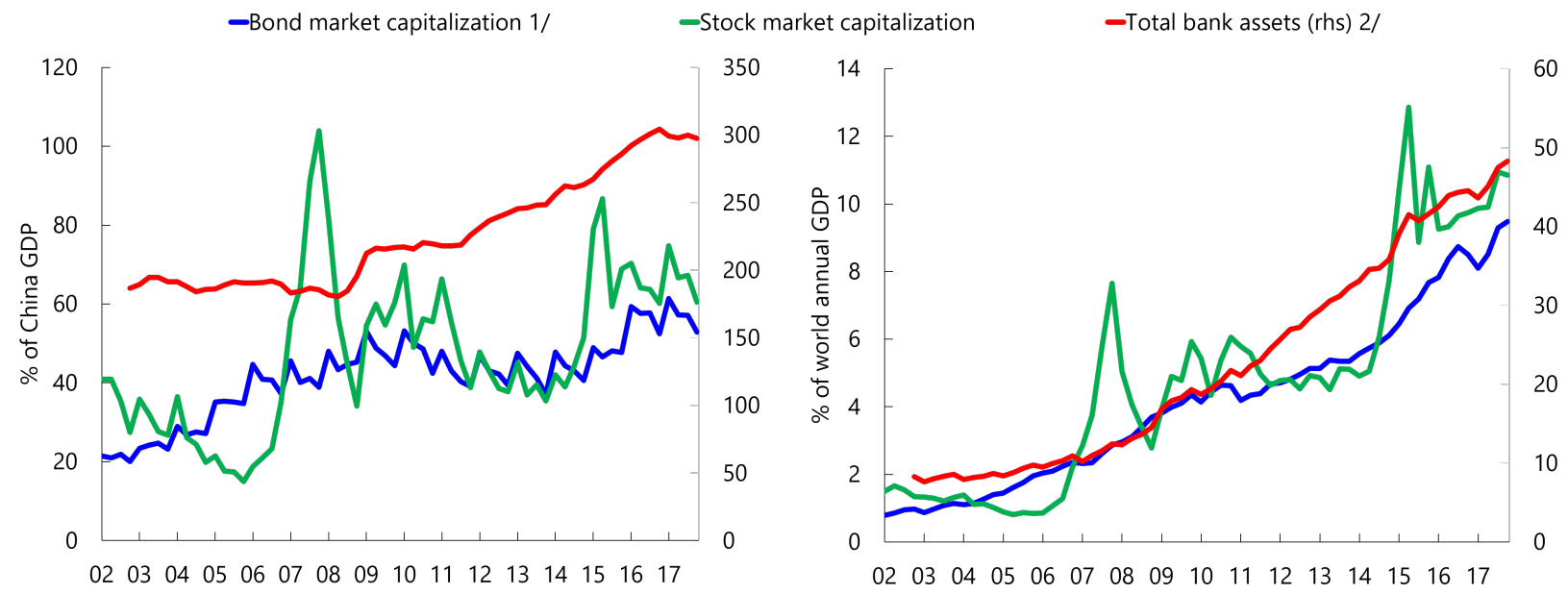

Sources: CEIC; IMF, World Economic Outlook; and IMF staff calculations.

$1 /$ Based on CCDC data coverage.

2/ Quarterly bank assets series is seasonally adjusted to facilitate visualization.

Figure 2: Foreign participation in China's stock and bond markets (assets held by overseas entities as \% of market size)

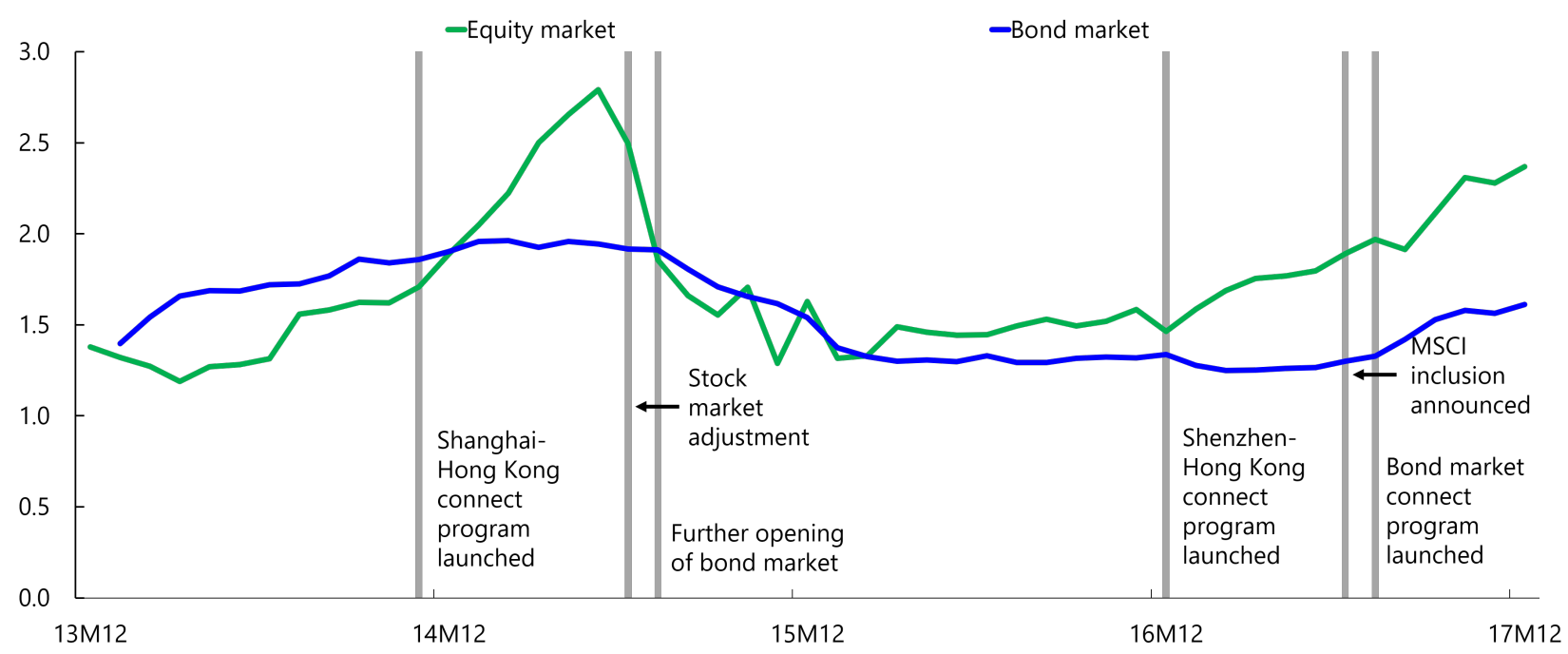

Sources: CEIC; People's Bank of China; and IMF staff calculations.

remains relatively low compared with international peers. Helped by landmark reforms in Chinese financial markets (such as the Shanghai-Hong Kong and Shenzhen-Hong Kong Stock Connect Programs), as well as by the inclusion of Chinese equities in the MSCI index, ${ }^{1}$ foreign participation in the Chinese stock market increased slightly in recent years (see Figure 2). Foreign equity holdings

\footnotetext{
${ }^{1}$ Guofeng (2015) describes the recent reforms. The inclusion of around 230 mainland-listed stocks in the MSCI index took effect on June 1, 2018. At the beginning, the share of Chinese A-shares would be about 0.7 percent of the MSCI index, with a future full inclusion weight of about 18 percent. Whereas Chinese bonds are not now included in any global index, if included, their index weight would be about one-third of the widely followed J.P. Morgan Emerging Markets Bond Index Global, according to the IMF (2016).
} 
are about 2.4 percent of total Chinese equity market capitalization. Foreign participation in Chinese bond markets is similarly small, just about 1.6 percent of the total value of bonds outstanding, with that share being stable in recent years.

In contrast, as shown in Figure 3 (panel 1), foreign participation in the stock markets of the United States (about 35 percent in 2017), Korea (33 percent), and Japan (17 percent) is much more important than in China. Only India displays comparably limited foreign stock-market participation (2.8 percent in 2017). The evidence is similar for the bond market (Figure 3, panel 2), with China substantially below its peers, including India, in foreign bond-market participation.

Figure 3: Foreign participation in China's stock and bond markets

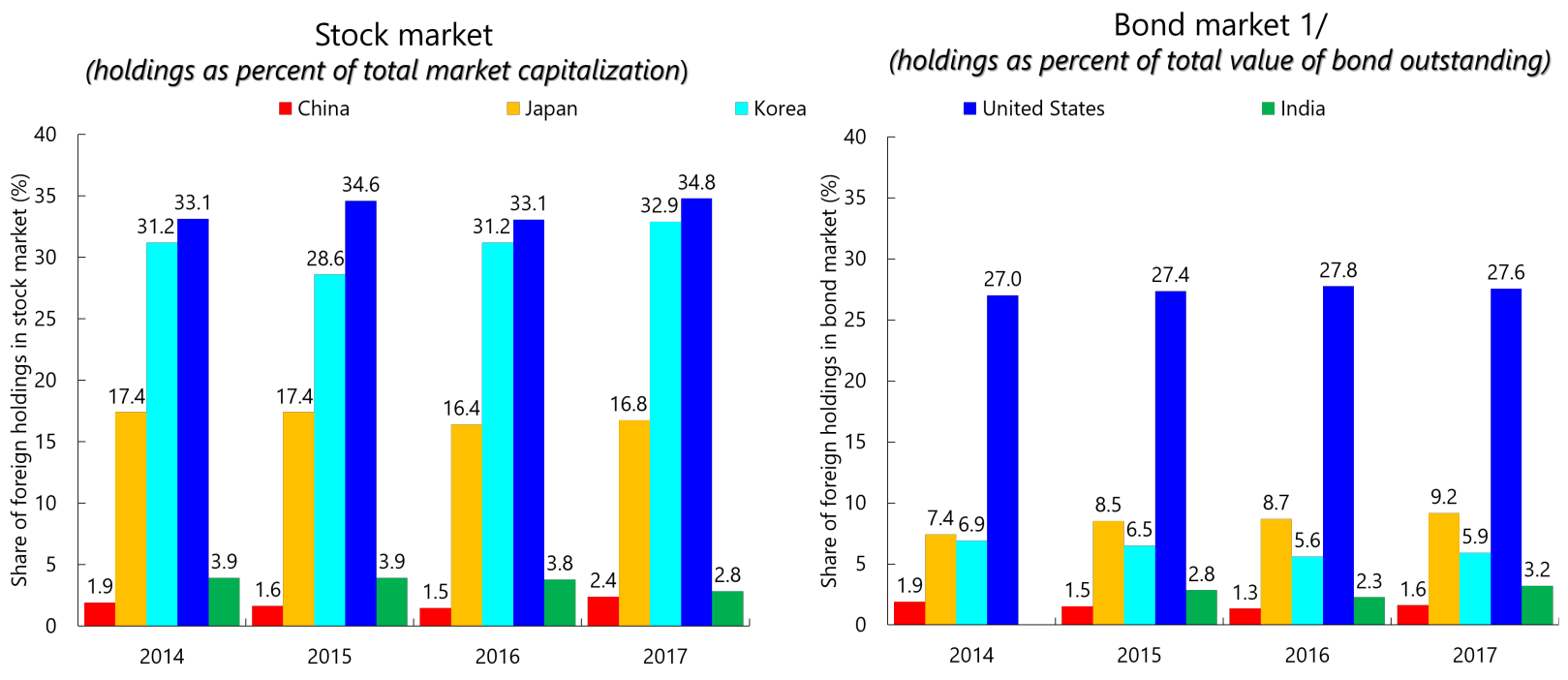

Sources: Bank of Japan; CEIC; Financial Supervisory Service; Financial Supervisory Service, Korea; Haver Analytics; Ministry of Finance, Japan; People's Bank of China; Reserve Bank of India; SIMFA; U.S. Department of Treasury; and IMF staff calculations.

1/ Data for India only includes government securities.

Limited foreign participation in China's financial markets is also visible in IMF Balance of Payments data, highlighting the wide scope for further external integration of those markets. The international investment position of China as of 2015 showed that its liabilities to foreigners (claims of nonresidents on Chinese residents) were about 40 percent of domestic GDP (Figure 4, panel 1), substantially below the levels of the United States (about 160 percent of GDP), Japan (115 percent), as well as Korea (65 percent) and India (55 percent).

The composition of these liabilities across countries also reflects the scope for further integration of China in both equity and, especially, bond markets. The share of portfolio equity and bonds is just $1 / 5$ of total Chinese external liabilities, a much lower share than for the United States (3/4 of total external liabilities), Japan (3/5 of total external liabilities), Korea (3/5 of total external liabilities), and India (2/5 of total external liabilities). A similar picture (Figure 4, panel 2) prevails on the asset side (Chinese residents' holdings of foreign assets), highlighting the still modest external diversification of Chinese wealth, especially of portfolio equity and debt. 
Figure 4: International Investment Position
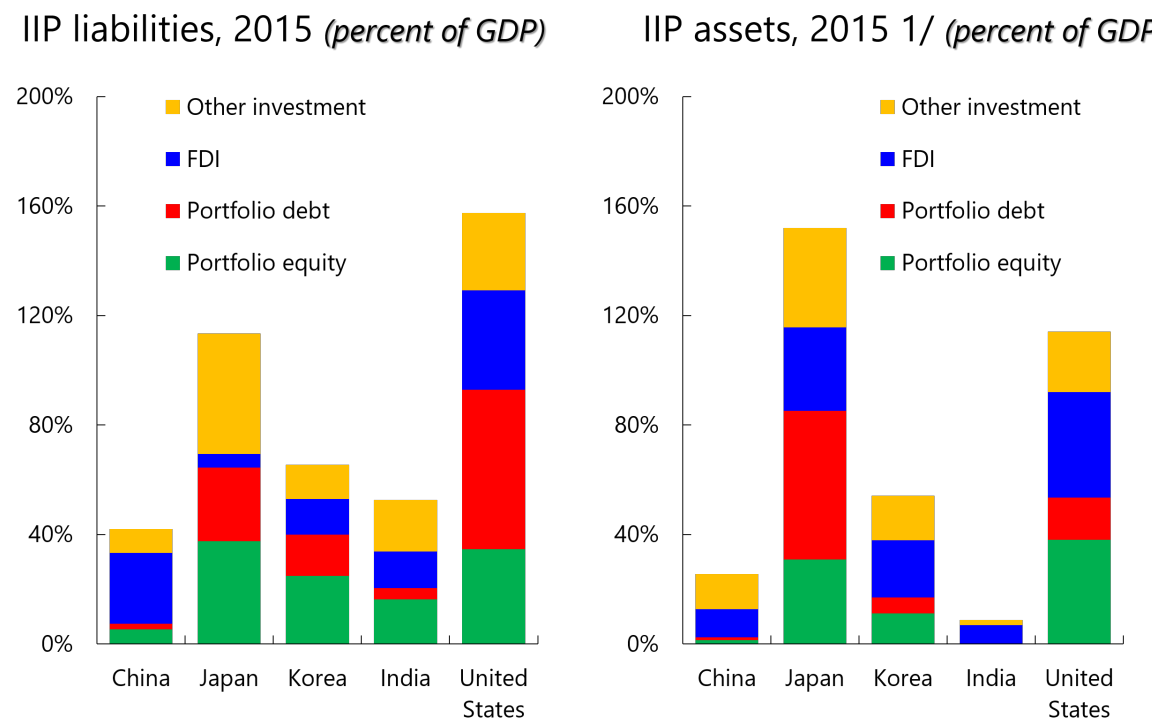

Sources: Lane and Milesi-Ferretti (2017); IMF, Balance of Payment Statistics; and IMF staff calculations. $1 /$ Net of reserves.

\section{Further Liberalization OF China's Bond Market}

So, the overall size of financial markets in China has increased, with a relatively minor increase in foreign sector participation and still-low international integration relative to peer economies. This section explores the characteristics of the country's bond markets and the types of bonds that might attract foreign investors through further cross-border liberalization. ${ }^{2}$

Chinese bonds outstanding at the end of 2017 were high in absolute terms, with a stock of about $\$ 11$ trillion at the end of 2017 (Figure 5), more than Korea (about \$2 trillion), similar to Japan (\$12 trillion), but not comparable yet with the euro area (\$20 trillion) or the United States ( $\$ 41$ trillion).

Unlike Japan, Korea, and even the euro area and the United States, the issuers of Chinese bonds are more concentrated in the nongovernment sector (although for China that includes important state-owned enterprises and various government-sponsored vehicles). Nonetheless, most foreign holdings of Chinese bonds are concentrated in government instruments. This situation resembles

\footnotetext{
${ }^{2}$ As in the case of other countries, foreign investors could also increase exposure to a particular country through off-shore markets. In the case of China, this is especially the case through the off-shore markets operating in Hong Kong, where bonds can be also issued in renminbi (usually known as Dim Sum bonds). Nonetheless, the small foreign participation in the Chinese onshore bond market does not seem to be driven by the availability of bonds in these offshore markets. In addition to maturity considerations (that is, often shorter maturity in offshore markets), the activity in these offshore markets is influenced by both the offshore issuance of bonds by Chinese companies that need to be authorized by the National Development and Reform Commission (China's economic planning ministry and regulator for enterprise bonds), and also net renminbi outflows from the mainland, which provides a large part of the liquidity and are also regulated from the mainland. Moreover, the launch of the Bond Connect program-which liberalizes some regulations by allowing institutional international investors to trade onshore bonds through Hong Kong-has increased foreign holdings in onshore markets in 2018 according to Hong Kong Exchange (2018).
} 
Figure 5: Total value of bond outstanding, end 2017

(USD trillions)

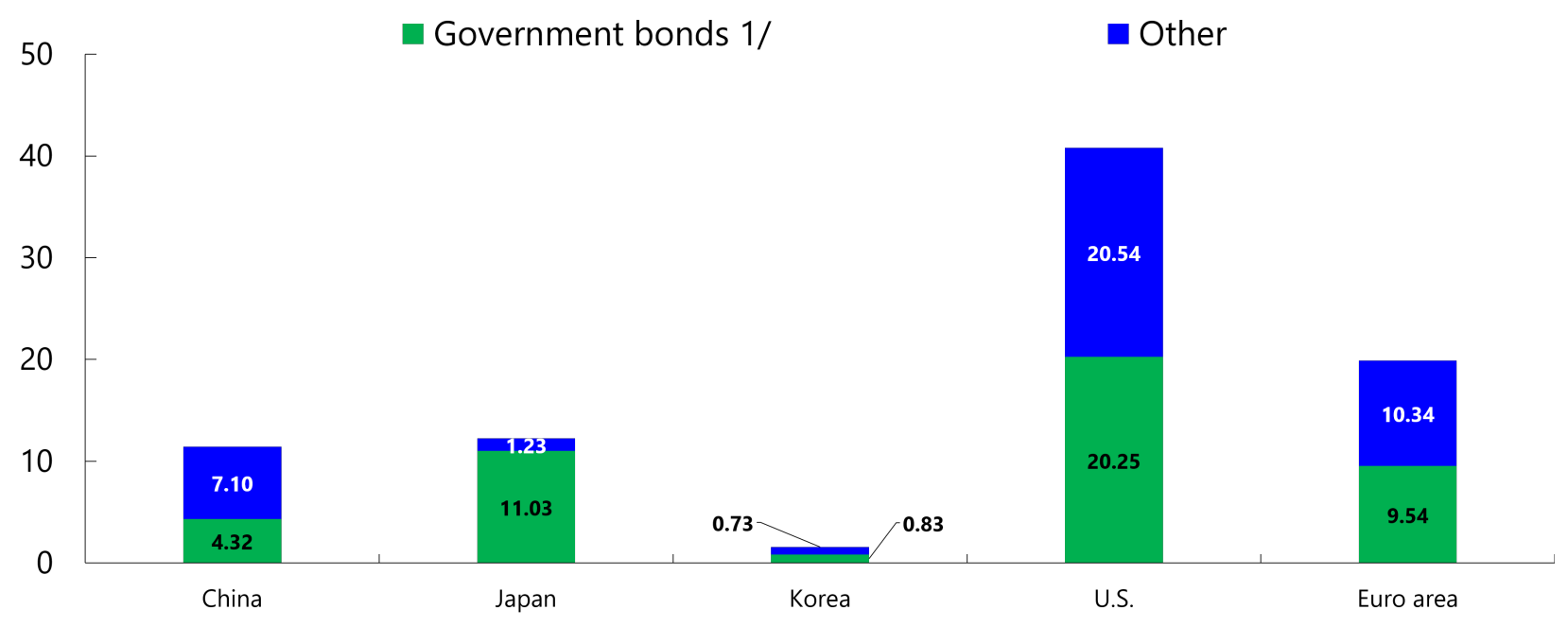

Sources: People's Bank of China; European Central Bank; Bank of Japan; Financial Supervisory Service, Korea; Bank of Korea; SIFMA.

1/ Government bonds cover bonds issued by the general government (central, state and local government accounts, social security funds and non-market non-profit institutions controlled and mainly financed by government units).

Figure 6: Breakdown of foreign holdings by type of bonds, 2016 (percent of total)

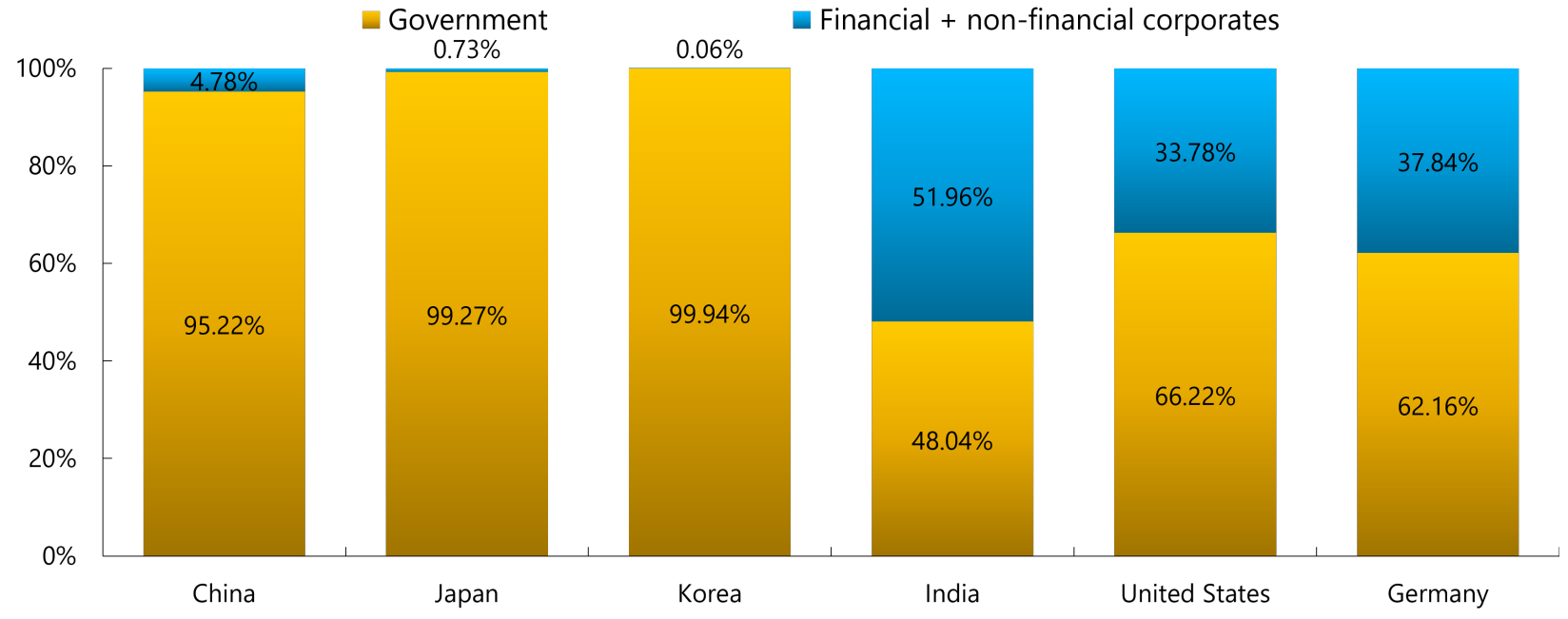

Sources: U.S. Department of Treasury; Haver Analytics; Deutsche Bundesbank; Bank of Japan; Financial Supervisory Service, Korea; Reserve Bank of India; National Securities Depository, India; and IMF staff calculations.

Japan's and Korea's, but is far from those of the United States, India, and euro area countries such as Germany, where nonresidents contribute a substantial fraction of the private sector's bond financing. ${ }^{3}$ In this context, further liberalization of the bond market in China could help the private

\footnotetext{
${ }^{3}$ The May 2017 Research Report of the Hong Kong Exchange finds that foreign financial institutions tend predominantly to hold Chinese sovereign bonds and the most highly rated corporate bonds as part of their renminbi reserves due to China's weak market infrastructure, particularly the rather low credibility of local credit rating agencies.
} 
sector diversify funding, improve liquidity, and lengthen borrowing maturities.

In terms of pricing, the evolution of the Chinese bond yield curve reflects higher nominal yields than either U.S. or euro area bonds, as well as a degree of co-movement in the evolution of Chinese yields relative to those countries despite China's closed capital account. Figure 7 depicts the bond yields at the end of April 2018, as well as the yield curve before the beginning of monetary normalization in the United States in December 2015 (dashed lines in Figure 7).

Figure 7: Yield curve of government bonds

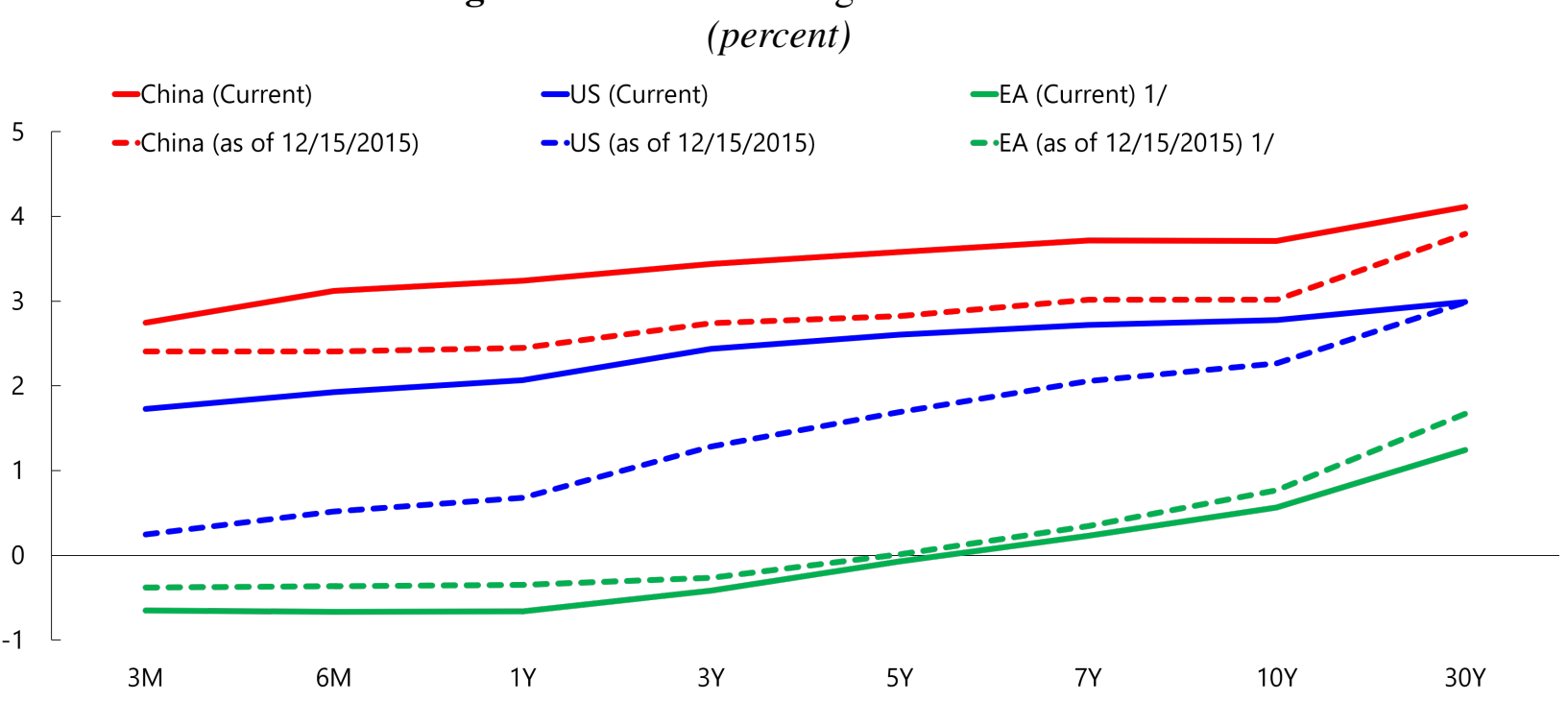

Source: Bloomberg L.P.

1/ Based on Euro Area AAA-rated government bonds.

Synchronized yield developments between China and the rest of the world do not necessarily imply the existence of big cross-currency arbitrage opportunities, both because of remaining capital controls and the relatively high cost of hedging currency risk. Figure 8 captures the relative hedged yield differentials between similar Chinese and US government bonds, using either onshore or offshore forwards. The hedged China-foreign yield differentials are not as positive as the unhedged ones, especially when using non-deliverable offshore forwards (green lines in Figure 8). Comparing covered twelve-month with three-month differentials, shorter maturity investments hedged onshore look somewhat more attractive to foreign investors. ${ }^{4}$

\footnotetext{
${ }^{4} \mathrm{Ma}$ and McCauley (2014) also document that the renminbi is priced cheaper onshore than offshore in the foreign exchange forward markets (as in Figure 8 as the higher cost of hedging using non-deliverable forwards compared with onshore forwards), and they associate this phenomenon with an appreciation of the renminbi and net private capital inflow pressures whenever the capital account opens up in China. Their projections for net inflows contrast with both He et al. (2012) and Bayoumi and Ohnsorge (2013), who project large increases in gross external positions (both assets and liabilities) but with private assets increasing more than liabilities. Estimating the net impact of further financial market liberalization is beyond the objectives of the paper and constitutes a very difficult task given the complexity and that relationships estimated with historical data would not necessarily be good predictors of the final direction of capital flows after structural policy changes_-which, in any case, will not necessarily be implemented all at once.
} 
Figure 8: FX-hedged and unhedged yield differentials
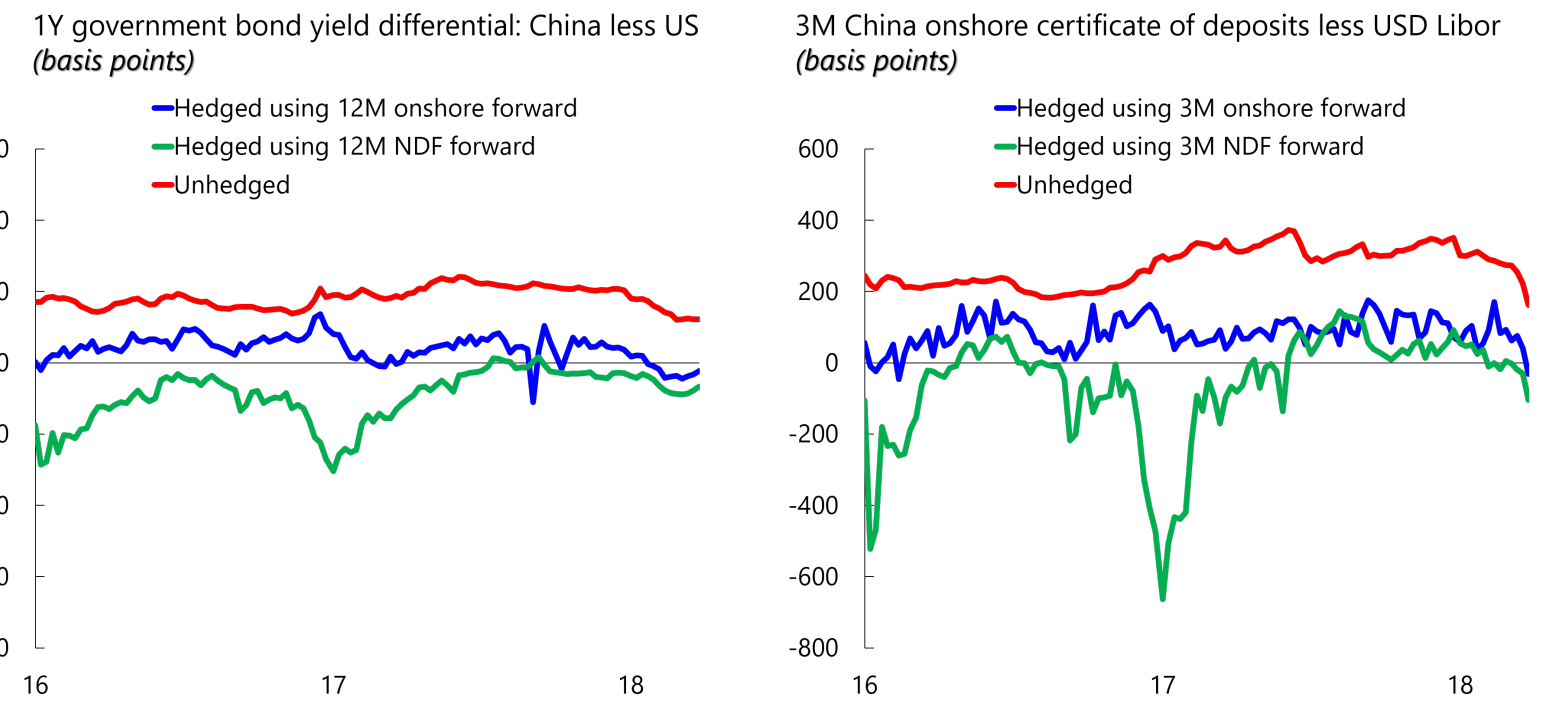

Sources: CFETS, Bloomberg L.P.; and IMF staff calculations.

In this context, it could be envisaged that the successful liberalization of the Chinese bond market would encompass not only further regulatory measures linked to the bond market itself (that is, by allowing further foreign participation in terms of buying and issuing bonds onshore), but that the resulting inflows and outflows of bonds would depend on several factors, including covered interest parity considerations, where both interest rate differentials and foreign exchange market considerations are important.

\section{MARKET OPENING AND INCREASING EXTERNAL INFLUENCES}

Further capital account liberalization, including deepening of the bond market, would increase the impact of current policies in key global financial centers (euro area, Japan, the United States) on capital flows to China. While the capital flows literature has covered the role of a number of external variables-variables usually now labelled as "push" factors-a consensus has emerged on the role of U.S. monetary policy (including unconventional monetary policies as reflected in Fratzscher, Lo Duca, and Straub 2018), risk aversion (as captured by the U.S. VIX, as stressed by Forbes and Warnock 2012, among others), and the U.S. dollar exchange rate (Bruno and Shin 2015) in helping explain the synchronicity of capital flows to emerging markets.

Despite continuation of the U.S. monetary policy tightening that started at the end of 2015, an interesting feature of the global economic expansion of 2017 is that capital inflows to both emerging and frontier markets rose. Figure 9 (panel 1) shows that this was also the case for China, which experienced an increase in bank-related inflows (captured under "other investment") and, to a lesser degree, in portfolio equity and debt inflows. 
Figure 9: Gross capital inflow

(percent of GDP)
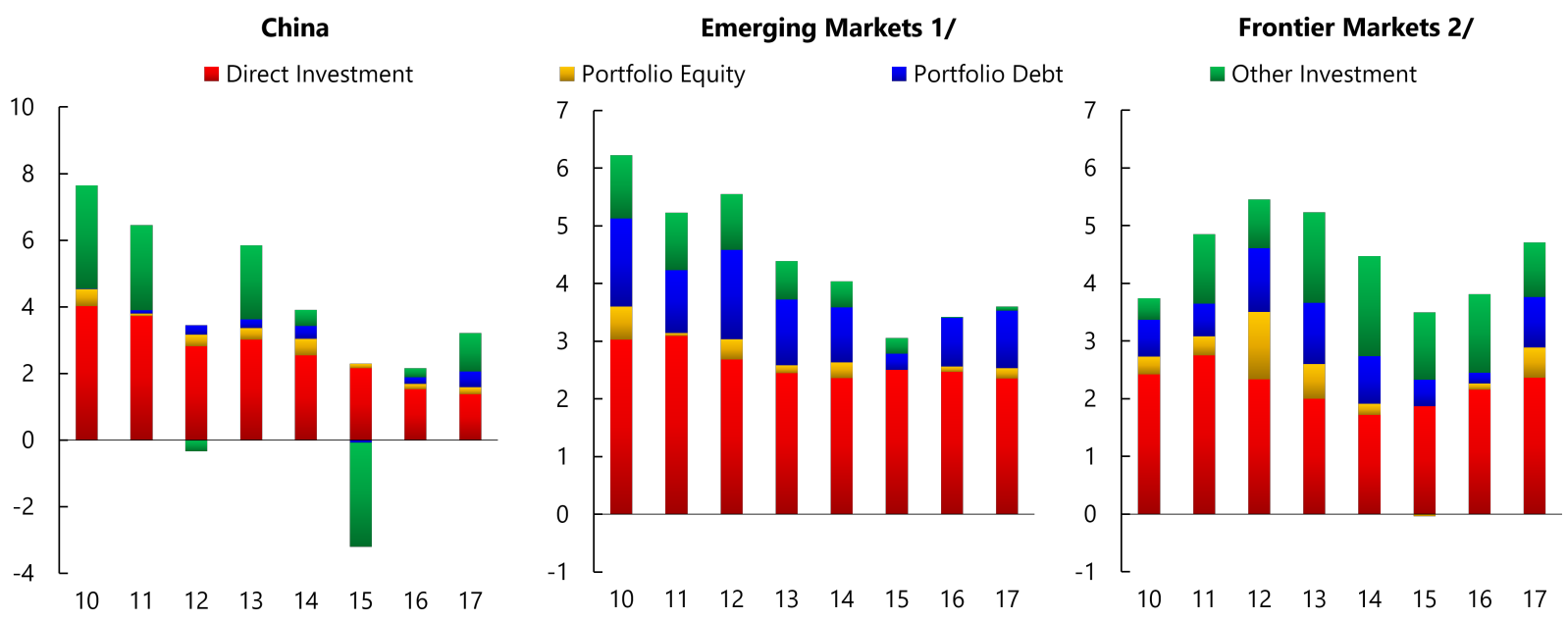

Sources: IMF, World Economic Outlook; IMF, Balance of Payment Statistics; and IMF staff calculations.

1/ Emerging markets data does not include China.

2/ Frontier market economies are defined as WEO low income economics included in MSCI frontier market index: Bangladesh, Burkina Faso, Benin, Guinea-Bissau, Côte d'Ivoire, Kenya, Mali, Niger, Nigeria, Senegal, Togo, Vietnam.

A large part of capital-inflow behavior in recent years is related to unconventional monetary policy in the United States. Taken from IMF (2017a), Figure 10 (panel 1) illustrates that U.S. unconventional monetary accommodation (as an expanding Federal Reserve balance sheet) has underpinned a significant portion of portfolio inflows to emerging markets. Both elevated global risk appetite (proxied by low U.S. VIX levels) and domestic pull factors explain the 2017 increase in capital inflows to emerging market economies. Overall, these model estimates suggest that the expected steady pace of Federal Reserve policy normalization over the next few years (both through balance sheet reduction and a rising Federal Funds rate) could reduce portfolio flows by a cumulative $\$ 75$ billion by late 2019 (panel 2, Figure 10, left vertical axis). ${ }^{5}$ Most emerging market economies should be able to handle this reduction in inflows, given their enhanced resilience and stronger growth outlooks.

A rapid increase in investor risk aversion would, however, have a more severe impact on portfolio inflows and could prove more challenging, including for China-but especially so for countries with greater dependence on external financing.

\footnotetext{
${ }^{5}$ As IMF 2017a highlights, estimates for portfolio flows are obtained using a model adapted from Koepke (2014). The model estimates the impact of external "push" and domestic "pull" variables on portfolio flows to emerging markets, consistent with the capital flows literature. The dependent variable reflects monthly data from the Institute of International Finance on nonresident portfolio flows to emerging market economies (that is, foreign purchases of emerging market stocks and bonds). Independent variables aim to capture push factors and pull factors. Push variables include a proxy for global risk aversion (either the U.S. corporate BBB spread over Treasuries or the U.S. VIX), threeyear-ahead expectations for the effective federal funds rate, and the change in assets held on the Federal Reserve's balance sheet. Pull variables include an emerging market economic surprise index compiled by Citigroup and the Morgan Stanley Capital International Emerging Markets Index.
} 
Figure 10: Fed's balance sheet and capital portfolio flows to emerging markets
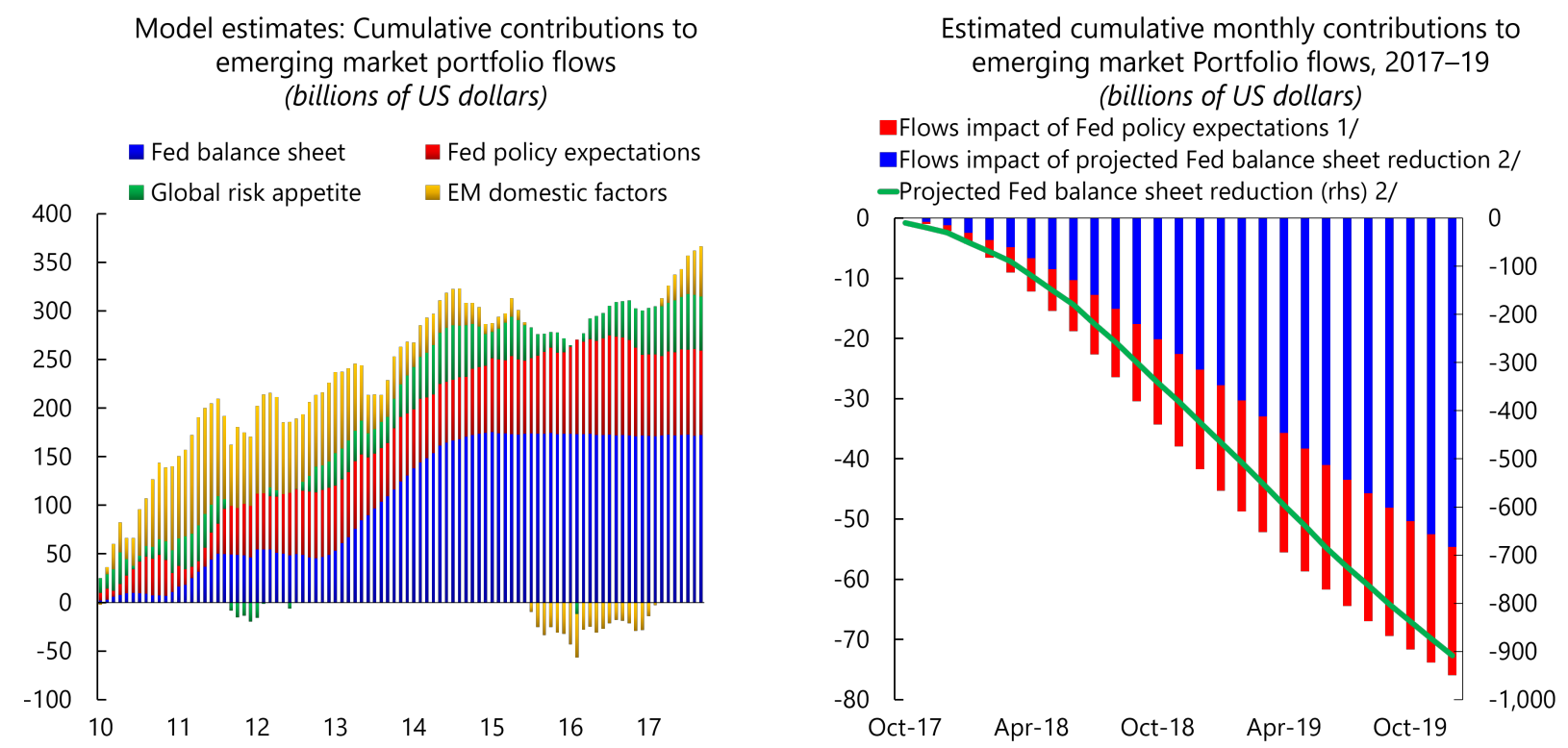

Sources: October 2017 GFSR and April 2018 GFSR.

$1 /$ WEO forecasts for the path of the federal funds rate.

2/ Fed's published plans for balance sheet normalization.

The relative foreign-exchange value of the U.S. dollar is another important driver of global financial conditions. China has moved to managing its exchange rate against a basket of currencies, rather than against the U.S. dollar alone, to dampen exposure to U.S. dollar variability. Nonetheless, the U.S. dollar exchange rate tends to have a substantial impact on capital inflows (see Bruno and Shin 2015 and Hofmann, Shim, and Shin 2017), and the U.S. dollar's steady depreciation against most currencies from early 2017 to early 2018 (panel 1 of Figure 11) had been one key driver of increasing capital inflows to emerging markets.

This depreciation spell, which stopped only in early 2018, stood at odds with the traditional (uncovered) interest rate parity condition. ${ }^{6}$ Take the U.S. dollar-euro relationship, for example. As indicated by the market's expectations of future short-term interest rates (proxied by the yield differential of Eurodollar-Euribor futures in the panel 2 in Figure 11), the market by the start of 2018 had priced in faster U.S. monetary tightening than the implied future interest rate differential path at the start of 2017. Similarly, the market also expected the future inflation differential between the euro area and the United States to narrow further relative to expectations of early 2017 (panel 2 of

\footnotetext{
${ }^{6}$ The traditional (risk-neutral) uncovered interest rate parity formula can be written as: $e_{t}=-\sum_{j=1}^{T}\left(i_{j, t}-i_{j, t}^{*}\right)+$ $\sum_{i=1}^{T}\left(\pi_{t+i}-\pi_{t+i}^{*}\right)+\bar{q}_{t+T+1}+\left(p_{t}-p_{t}^{*}\right)$, where an asterisk denotes a foreign variable, $e$ is the current nominal exchange rate (expressed in units of domestic currency per foreign currency, so that an increase in $e$ represents a depreciation of domestic currency), $i$ denotes a one-period nominal interest rate, $\pi$ is an inflation rate, and $q$ is the real exchange rate. As the future interest rate differential widens (the first term on the right) and future inflation-rate differentials narrow (the second term on the right), theory predicts that the domestic currency should appreciate. The only potential counteracting force in the equation is the long-term future real exchange rate $\left(\bar{q}_{t+T+1}\right)$, which captures a broad range of factors, including future fiscal policy conditions. Of course, adding risk premia to the above (to capture the failure of uncovered interest parity) would introduce an additional driver of the currency's relative value.
} 
Figure 11: Analyzing the evolution of the US dollar

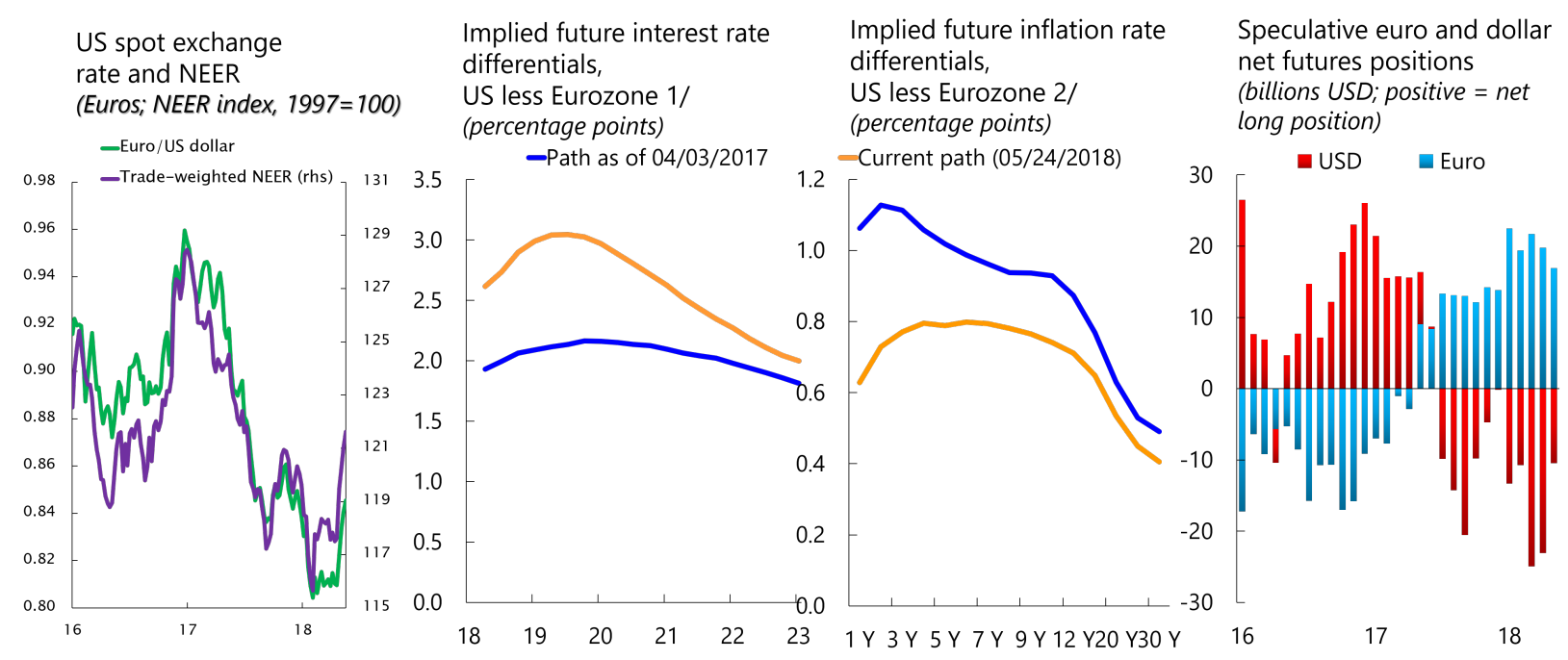

Sources: Haver Analytics, Bloomberg, L.P.; US Commodity Futures Trading Commission; and IMF staff calculations. 1/ Eurodollar less Euribor futures yield spreads. Each point represents the future-implied expected short-term interest rate differential at a specific date.

2/ Swap-implied future inflation rate differentials.

Figure 11). Both forces should have put upward pressure on the dollar, contrary to the evolution that actually occurred in the foreign exchange market.

The dollar's depreciating trend is reflected in foreign exchange futures market sentiment: speculative positions on the euro flipped from net short to net long after the euro began appreciating in early 2017, while the U.S. dollar has been heavily shorted more recently. One possible explanation for the puzzling U.S. dollar depreciation is that advanced-economy financial conditions have remained relatively loose, fueling capital outflows (and inflows to emerging market and frontier economies). Another potential explanation is that, given expected reductions in the Federal Reserve's balance sheet and impending bigger fiscal deficits in the United States, a great deal of U.S. dollar debt will have to be absorbed by markets in the coming years, weakening the currency, all else being equal.

More recently (especially since April 2018), the dollar has indeed shown more strength, as growth in the euro area and Japan has seemed to retreat from stronger rates in 2017. Nonetheless, as of the end of May 2018, the U.S. dollar had only partially reversed its cumulative depreciation after early 2017, and markets' speculative positioning on the currency remained net short-although at a lower level than at the end of 2017.

\section{Sensitivity of Capital Inflows to the Global Financial Cycle}

The U.S. variables discussed in the previous section are often identified as key drivers of the global financial cycle (Cerutti, Claessens, and Rose 2017). The increased integration of China into inter- 
national capital markets will likely increase its exposure to the global financial cycle, which, some have argued, could augment financial stability risks while weakening the scope for independent monetary policy (Rey 2016).

China's sensitivity to the global financial cycle is currently lower than other countries in terms of portfolio flows, especially portfolio debt securities. As Figure 12 shows, based on the analysis of Cerutti, Claessens, and Puy (2017), in China, just 5 percent of total variance in portfolio debt inflows is accounted for by a common factor empirically related to the global financial cycle. This is much lower than for the average Asian emerging market economy (18 percent) and for the average of all emerging market economies (13 percent). The finding is in line with the reality that foreign participation is simply not as large in China's bond market as it is elsewhere.

Figure 12: Sensitivity to EM common factors by type of capital flow (percent of total variance accounted by the common global factor)

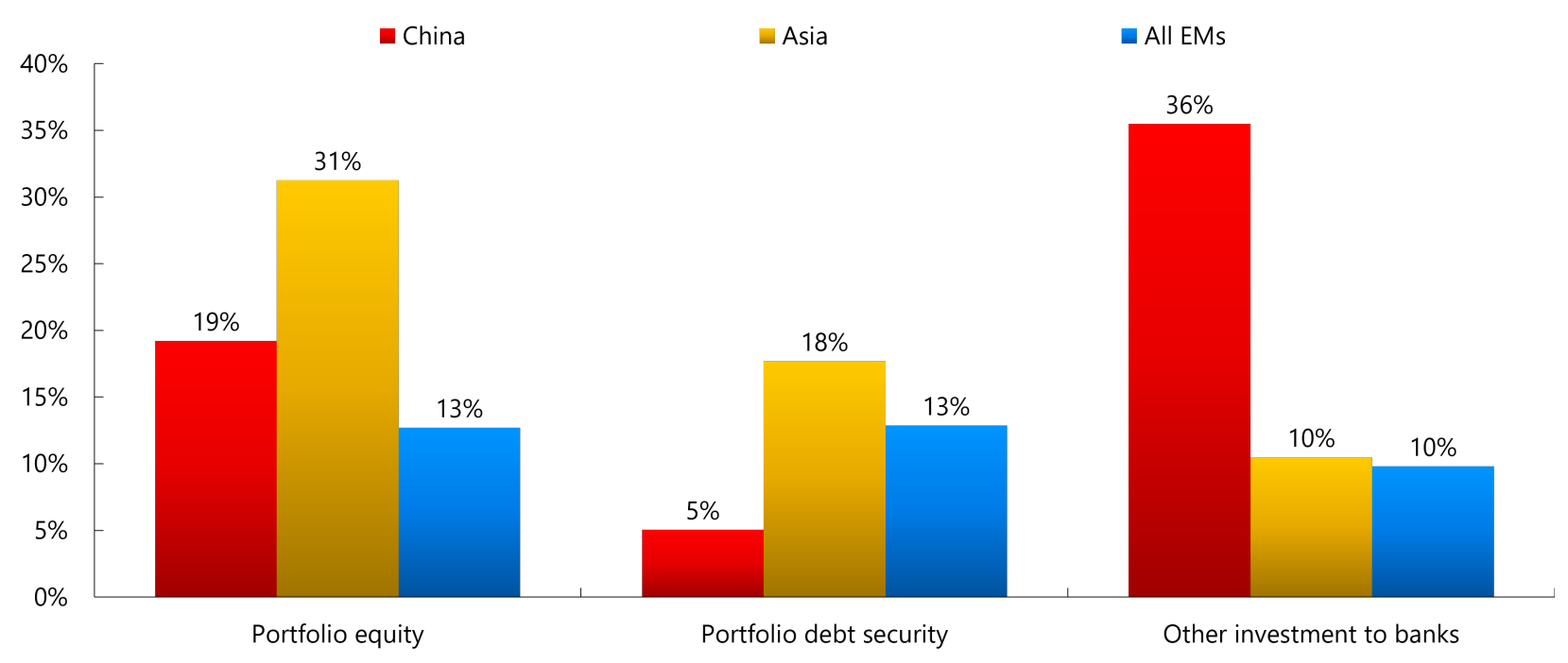

Source: Cerutti, Claessens and Puy (2017).

In this context, it is likely that further liberalization in the bond market would probably elevate sensitivity to the global financial cycle. Using the estimated loading coefficient for the common factor estimated by Cerutti, Claessens, and Puy (2017), along with countries' exposures to global investors, one can visualize in Figure 13 (panel 1) how China's low bond inflow sensitivity is related empirically to the relatively low participation of global investors. Based on this crosscountry evidence, it is foreseen that further liberalization of the Chinese bond market will increase sensitivity to global developments, as has happened in other countries. This is less the case for equity inflows, where China ranks in the middle of the emerging economy group (panel 2, Figure 13). 
Figure 13: Exposure to global investors and sensitivity to the Global Financial Crisis
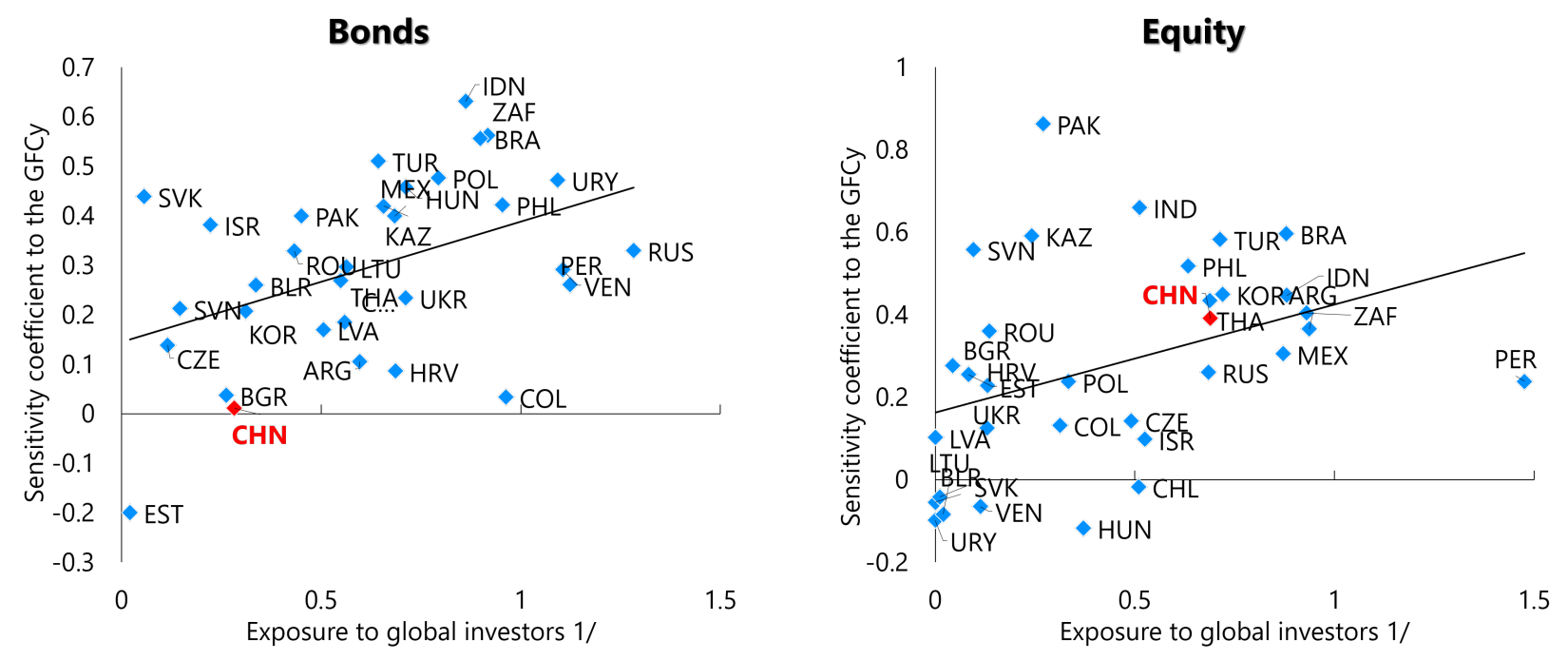

Source: Cerutti, Claessens and Puy (2017).

1/ A weight above (below) one implies that the country was over- (under-) represented in global investor flows relative to total BOP flows. Peru is an outlier in terms exposure to global investors in equity markets due to the peculiar incorporation in offshore markets of Peru's largest domestic bank holding company and a large Peruvian mining company.

\section{Conclusion}

Room remains substantial for further integration of China into the global bond market, which would advance the broader project of sustainably integrating the country into international trade and finance. But this process will likely increase exposure to the global financial cycle.

This paper concludes that, for monetary autonomy, the cost would not be large given China's size and especially under a more flexible exchange rate framework than the current one, supported by a well-articulated inflation-targeting framework. ${ }^{7}$ For financial stability, however, work remains to be done, as both China's government and the IMF recognize (IMF 2017b).

Other advantages, from a domestic Chinese perspective, include that an influx of foreign capital would help diversify funding and improve liquidity, maturities, and transparency in the local bond markets. Similarly, further geographical diversification by Chinese resident financial asset holders (including in the private sector) would improve domestic asset allocations.

Finally, from a global perspective and taking into account that China offers a potentially large pool of savings, better integration into the international bond market could promote a significantly more productive allocation of the world's savings, to the benefit of lenders and borrowers alike.

\footnotetext{
${ }^{7}$ Greater flexibility is often cited inside and outside of China, but much progress remains to be made. Transition could proceed along broad lines as laid out in Obstfeld (2007), with due attention to the need to refine an appropriate inflation-targeting framework, as discussed in several of the essays in Ming and Schipke (2017).
} 


\section{REFERENCES}

Bayoumi, T. and F. Ohnsorge. 2013. "Do Inflows or Outflows Dominate? Global Implications of Capital Account Liberalization in China.” IMF Working Paper 13/189, IMF, Washington.

Bruno, Valentina and Hyun Song Shin. 2015. "Cross-Border Banking and Global Liquidity." Review of Economic Studies 82 (2): 535-564.

Cerutti, E., Claessens, S. and D. Puy. 2017. "Push Factors and Capital Flows to Emerging Countries: Why Knowing Your Lender Matters More than Fundamentals.” Unpublished.

Cerutti, E., Claessens, S. and A. Rose. 2017. "How Important is the Global Financial Cycle? Evidence from Capital Flows." IMF Working Paper 17/193.

Forbes, K. and F. Warnock. 2012. "Capital Flow Waves: Surges, Stops, Flight, and Retrenchment." Journal of International Economics 88 (2): 235-251

Fratzscher, M., Lo Duca, M. and R. Straub. 2018. "On the International Spillovers of U.S. quantitative Easing." Economic Journal 608 (128): 330-377.

Guofeng, S. 2015. Financial Reforms in Modern China. A Frontbencher's Perspective. New York: Palgrave Macmillan.

He, D., Cheung, L., Zhang, W. and T. Wu. 2012. "How Would Capital Account Liberalization Affect China's Capital Flows and the Renminbi Wu Real Exchange Rates?" China and World Economy 20 (6): 29-54.

Hofmann, Boris, Shim, Ilhyock and Hyun Song Shin. 2017. "Sovereign Yields and the RiskTaking Channel of Currency Appreciation.” Bank for International Settlements Working Paper 538, BIS, Basel (May revised version).

Hong Kong Exchange. 2017. “Tapping into China's Domestic Bond Market—An International Perspective." HKEx research report, May.

Hong Kong Exchange. 2018. "Bond Connect Celebrates First Anniversary" Press release, July 3, 2018. Available at https://www.hkex.com.hk/News/News-Release/2018/180703news?sc $l$ ang $=$ en

IMF. 2016. "The Growing Importance of Financial Spillovers from Emerging Market Economies.” Chapter 2 in Global Financial Stability Report. Washington, DC, April.

—. 2017a. "Is Growth at Risk?" Chapter 1 in Global Financial Stability Report. Washington, DC, October.

- 2017b. People's Republic of China: Financial System Stability Assessment. Washington, DC, December.

Koepke, R. 2014. “Fed Policy Expectations and Portfolio Flows to Emerging Markets." Institute of International Finance Working Paper, Washington, DC.

Ma, G. and R. McCauley. 2014. "Financial Openness of China and India: Implications for Capital Liberalization.” Bruegel Working Paper 2014/05, Bruegel. 
Ming, A. and A. Schipke, editors. 2017. "Strengthening Financial and Exchange Rate Frameworks: International Experience and Relevance for China." Proceedings of the People's Bank of China and IMF Fifth Joint Conference, Beijing.

Obstfeld, M.. 2007. “The Renminbi's Dollar Peg at the Crossroads." Monetary and Economic Studies, Institute for Monetary and Economic Studies, Bank of Japan 25 (S1): 29-56, December.

Rey, H. 2016. "International Channels of Transmission of Monetary Policy and the Mundellian Trilemma." IMF Economic Review 64 (1): 6-35. 